\title{
Back-to-the-future potential for autochthonous transmission of Aedes aegypti-transmitted viruses in eThekwini and urban coastal KwaZulu-Natal Province, South Africa
}

The Aedes aegypti (Linnaeus) mosquito transmits several important arboviruses, principally chikungunya (CHIKV), dengue (DENV), yellow fever (YFV) and Zika (ZIKV) $\cdot^{[1-4]}$ Ninety years ago this journal featured an account of the DENV-1 epidemic that crippled Durban during the summer of $1926 / 27 . .^{[5,6]}$ Summary estimates described 50000 sufferers and 60 attributed deaths along the coast between Kelso Junction and Stanger (KwaDukuza) and inland as far as Pinetown. ${ }^{[7]}$ Some residents suffered haemorrhagic manifestations now associated with repeat infections involving another of the four DENV types. ${ }^{[2,8-12]}$

A 1996 SAMJ editorial suggested that the 1926/27 epidemic occurred during a brace of remarkably wet years when the rainfall was five and eight times greater than the historical average. ${ }^{[13]}$ However, the Durban rainfall during 1925/26 was the lowest then on record and drought persisted through the first months of the 1927 epidemic, before plentiful March rains. ${ }^{[14]}$ Empty skies compounded structural water supply challenges later relieved by completion of the Shongweni Water Scheme. ${ }^{[15]}$

The 1926/27 epidemic was not an anomaly. In the early 1870s, a pandemic often identified as 'dengue' - but more likely in fact chikungunya - swept through Indian Ocean ports. ${ }^{[16-20]}$ The pandemic reached Mauritius in $1873 .{ }^{[21,22]}$ In late January 1874 , an epidemic resembling chikungunya took hold in Durban: 'a low fever, accompanied by rheumatic pain', affecting black and white populations alike, 'almost put a stop to business. ${ }^{[23]}$ 'The first symptoms of the attack are stiffness and soreness in the legs and joints, pains in the head, and tightness in the chest', The Natal Mercury detailed. 'Then the fever soon shows itself and prostrates the victim. There is nothing of fatal character about the sickness but it completely knocks up those it attacks, for at least two or three days. ${ }^{[24]}$ Four summers later, in March 1878, the port town's district surgeon reported that 'this is the first time dengue has shown itself epidemically in this Colony,' ${ }^{[25]}$ and The Natal Mercury observed that 'at least every other person has suffered. ${ }^{[26]}$

In addition to the epidemics in 1874 and 1878 , medical observers reported disease events they described as 'dengue' during 10 additional summers over the next 50 years. ${ }^{[27-28]}$ Eight of those 12 years saw rainfall in Durban below the historical average (Table 1), often coincident with El Niño-associated drought. ${ }^{[29-31]}$ While the precise viral aetiologies of outbreaks and epidemics prior to 1926/27 are elusive, the better documented occurrences of probable chikungunya or dengue point to the presence of human-biting, virus-transmitting Ae. aegypti populations and recurring intersections with water stress.

In 2016, during a summer marked by El Niño drought, eThekwini's dengue history went unmentioned after the World Health Organization declared Zika a public health emergency of international concern. Leading South African health officials made statements to the press ${ }^{[32-36]}$ and Parliament's Portfolio Committee on Health, ${ }^{[37]}$ dismissing the vector capacity and competence of the country's Ae. aegypti populations, regardless of region. All six urgent actions prioritised by the Department of Health focused on travellers and the translocation of mosquitoes from abroad. ${ }^{[38]}$ The more nuanced assessment that National Institute for Communicable Diseases officials placed in this journal ${ }^{[39]}$ referenced unspecified 'prediction models based on the distribution of Ae. aegypti' as indicating a low risk for autochthonous viral transmission.
Table 1. Summers with reports of dengue-like illness in the Durban area and recorded rainfall at Durban Botanical Gardens, 1873/74 - 1926/27

\begin{tabular}{llll}
\hline $\begin{array}{l}\text { Year } \\
\text { (July - June)/ } \\
\text { summer }\end{array}$ & $\begin{array}{l}\text { Number of } \\
\text { days with } \\
\text { recorded } \\
\text { rainfall }^{[14]}\end{array}$ & $\begin{array}{l}\text { Recorded } \\
\text { rainfall }^{[14]} \\
(\mathbf{m m})^{*}\end{array}$ & $\begin{array}{l}\text { Rainfall as \% more } \\
\text { or less than annual } \\
\text { average 1871 - 1997 } \\
(\mathbf{1 ~ 0 0 2 ~} \mathbf{~ m m})^{[31]}\end{array}$ \\
\hline $1873 / 74$ & 137 & 1283.5 & +28.1 \\
$1877 / 78$ & 136 & 865.3 & -13.6 \\
$1891 / 92$ & 126 & 783.5 & -21.8 \\
$1895 / 96$ & 136 & 917.7 & -8.5 \\
$1896 / 97$ & 119 & 954.0 & -4.8 \\
$1897 / 98$ & 138 & 992.8 & -1.0 \\
$1899 / 00$ & 127 & 686.5 & -31.5 \\
$1900 / 01$ & 127 & 1119.3 & +11.7 \\
$1901 / 02$ & 127 & 1242.0 & +24.0 \\
$1913 / 14$ & 107 & 878.0 & -12.4 \\
$1925 / 26$ & 98 & 669.0 & -33.3 \\
$1926 / 27$ & 106 & 842.7 & -15.9 \\
\hline
\end{tabular}

*Documentary records recorded in inches, converted here into millimetres.

Ae. aegypti is a polymorphic species whose populations exhibit variable traits influenced by genetics and environment - for example, colour pattern, bloodmeal preference, egg-laying site selection and vector competence. ${ }^{[40]}$ A 1991 morphology-focused study reached a similar conclusion: 'in South Africa Ae. aegypti is a single polymorphic species displaying plasticity in its manbiting behavior. ${ }^{[41]}$ Entomologists in the 1950s and 1990s described focally abundant, domestic, human-biting Ae. aegypti populations in eThekwini and the KwaZulu-Natal (KZN) coast. ${ }^{[42-44]}$ Between 1970 and 2002, vector competence tests yielded the following results: $A e$. aegypti populations from both ends of $\mathrm{KZN}-\mathrm{a}$ forest population from Ndumu and another from Glenmore Beach - were readily infected with CHIKV at viral titres $>5.3$ logs and capably transmitted the virus; ${ }^{[45,46]}$ Ae. aegypti from eThekwini were competent vectors of DENV-1 and DENV-2, albeit with lower efficiency than seen in South America; ${ }^{[47]}$ and Ae. aegypti from eThekwini were relatively poor vectors of $\mathrm{YFV}^{[48]}$

Less competent vectors still warrant consideration. ${ }^{[49]}$ From November through April, eThekwini summers favour Ae. aegypti abundance, with average high temperatures of $25-28^{\circ} \mathrm{C}$, relative humidity around $80 \%$, and summer rainfall. ${ }^{[50-54]}$ If the city's Ae. aegypti mosquitoes obtain bloodmeals containing CHIKV, DENV or ZIKV from infected visitors or returning residents - and subsequently survive beyond the virus's extrinsic incubation period (EIP) within mosquitoes - local transmission could result. Most of eThekwini's 3.5 million residents presumably have no acquired immunity to these viruses.

Entrenched inequality deprives many eThekwini residents of protection against blood-feeding Ae. aegypti afforded by goodquality dwelling construction, in-house piped water, and airconditioning. ${ }^{[55-57]}$ A third of eThekwini households are located in informal settlements. ${ }^{[58]}$ Barely $60 \%$ of city households enjoy in-house piped water. ${ }^{[59]}$ Where piped water is present, residents 
may still collect and store water to hedge against prohibitive costs or restrictions and interruptions.

This is not to suggest that eThekwini's well-to-do are unlikely to be affected. Their disposable income and international travel make them candidates for virus importation. As in 1927 - when dengue beset Berea households - water-holding receptacles and vegetation prized in the gardens of the wealthier classes can foster and shelter Ae. aegypti, while outdoor living areas can increase vector exposure during peak morning and evening biting times. ${ }^{[0,61]}$

Up to $80 \%$ of ZIKV and $75 \%$ of DENV infections may be asymptomatic. ${ }^{[62,63]}$ Moreover, a 2015 study revealed that people with asymptomatic DENV infections can still infect biting mosquitoes. ${ }^{[64]}$ Visitors or returning residents may infect blood-feeding Ae. aegypti without displaying signs of illness. This understanding - and the reality that 7 in 10 eThekwini households depend upon public healthcare facilities ${ }^{[65]}$ - blunts the sensitivity of passive disease surveillance focused on recent travellers and dominated by private sector test requests.

Looking forward, resident mobility as well as expansionary goals for the city's aerotropolis ${ }^{[6,66]}$ and international tourism ${ }^{[68]}$ could increase the possibilities for virus importation. In addition, climate change may make summers more conducive to virus transmission. Projections suggest temperature increases in eThekwini of 1.5 $2.5^{\circ} \mathrm{C}$ by 2065 and, by 2100 , a rise of $3-5^{\circ} \mathrm{C} \cdot{ }^{[69]}$ Higher temperatures shorten EIPs in Ae. aegypti. One DENV study found EIPs of $\geq 12$ days at $30^{\circ} \mathrm{C}$, but 7 days at $32-35^{\circ} \mathrm{C} ;{ }^{[70]}$ another reported EIPs of 9 days at $26-28^{\circ} \mathrm{C}$ that fell to 5 days at $30^{\circ} \mathrm{C} \cdot{ }^{[71]}$ While the net influence rising temperatures will exert on larval development, adult size and abundance, female biting rates, EIPs and adult longevity is complex, warmer summers in eThekwini may increase the likelihood that $A e$. aegypti - if infected - will survive long enough to deliver infecting bites.

Human adaptation to water insecurity and climate change may influence eThekwini's disease ecology more than the direct impact of rising temperatures. ${ }^{[72,73]}$ Rainwater tanks were a common feature of Durban's urban ecology during its dengue past. ${ }^{[74-79]}$ Residents, climate change planners, water officials and NGOs who practise or promote rainwater harvesting unwittingly restore one of Ae. aegypti's most prolific larval habitats from yesteryear. ${ }^{[80-85]}$ These considerations warrant further study and engagement beyond the health sector with the potential for Ae. aegypti-transmitted viruses in urban coastal KZN.

\section{Philip D Rotz}

PhD candidate, Environmental History/African History, History

Department/African Studies Center, Boston University, USA; and affiliated researcher, 2014 - 2016, School of Social Sciences,

University of KwaZulu-Natal, Durban, South Africa protz@bu.edu

Acknowledgements. I am grateful for stimulating exchanges with past and present staff of South Africa's National Institute for Communicable Diseases and the eThekwini Health Unit from 2014 to 2016. Any errors are wholly my own.

Author contributions. Sole author.

Funding. This text draws on dissertation fieldwork supported by a Graduate Research Abroad Fellowship from Boston University and a Fulbright-Hays Doctoral Dissertation Research Abroad Fellowship from the US Government's Department of Education. The composition of a more expansive essay on this subject (in press) received support from the Pardee Center for the Study of the Longer-Range Future at Boston University.

Conflicts of interest. None.

1. World Health Organization. Chikungunya Factsheet. Geneva: WHO; updated April 2017. http://www. who.int/mediacentre/factsheets/fs327/en/ (accessed 15 July 2017).

2. World Health Organization. Dengue and Severe Dengue Factsheet. Geneva: WHO; updated April 2017. http://www.who.int/mediacentre/factsheets/s117/en/ (accessed 15 July 2017).

3. World Health Organization. Yellow Fever Factsheet. Geneva: WHO; updated May 2016. http://www. who.int/mediacentre/factsheets/fs100/en/ (accessed 12 October 2016).

4. World Health Organization. Zika Factsheet. Geneva: WHO; updated September 2016. http://www. who.int/mediacentre/factsheets/zika/en/ (accessed 12 October 2016).

5. Edington AD. 'Dengue' as seen in the recent epidemic in Durban. J Med Assoc S Afr 1927;1(17):446-448.

6. Kokernot RH, Smithburn KC, Weinbren MP. Neutralising antibodies to arthropod-borne viruses in 6. Kokernot RH, Smithburn KC, Weinbren MP. Neutralising antibodies to arthropod
human and animals in the Union of South Africa. J Immunol 1956;77(5):313-323.

7. Department of Public Health, Union of South Africa. Annual Report of the Department of Public Department of Public Health, Union of South Africa. Annual Report of the Department of P
Health, Year Ended 30th June 1927. Pretoria: Government Printing and Stationery Office, 1927.

8. Katzelnick LC, Fonville JM, Gromowski GD, et al. Dengue viruses cluster antigenically but not as discrete serotypes. Science 2015;349(6254):1338-1343. https://doi.org/10.1126/science.aac5017

9. Guzman MG, Alvarex M, Halstead SB. Secondary infection as a risk factor for dengue hemorrhagic fever/dengue shock syndrome: An historical perspective and role of antibody-dependent enhancement. Arch Virol 2013;158(7):1445-1459. https://doi.org/10.1007/s00705-013-1645-3

10. Correspondence from Assistant Health Officer, Durban, to Secretary for Public Health re: 'Dengue', 19 March 1927. Folder 61/12, Box 580, Series GES (Records of the Union Department of Public Health), National Archives Repository, Public Records of Central Government since 1910, National Archives and Record Service of South Africa.

11. Correspondence from Assistant Health Officer, Durban, to Secretary for Public Health re: 'Dengue Fever: Durban', 22 March 1927. Folder 61/12, Box 580, Series GES (Records of the Union Department of Public Health), National Archives Repository, Public Records of Central Government since 1910, National Archives and Record Service of South Africa.

12. Kuno G. Emergence of the severe syndrome and mortality associated with dengue and dengue-like Kuno G. Emergence of the severe syndrome and mortality associated with dengue and dengue-like
illness: Historical records (1890 to 1950) and their compatibility with current hypotheses on the shift of dilness: Historical records ( 1890 to 1950) and their compatibility with current hypotheses on the shift of
disease manifestation. Clin Microbiol Rev 2009;22(2):186-201. https://doi.org/10.1128/cmr.00052-08

13. Jupp PG, Kemp A. What is the potential for future outbreaks of chikungunya, dengue and yellow fever in southern Africa? S Afr Med J 1996;86(1):35-37.

14. Durban Borough Water Engineer. Annual Report for year ending 31st July, 1927. In: Durban Corporation. Mayor's Minute, with Departmental Reports, Appendices, and Balance Sheets for the Municipal Year ended 31st July 1927. Durban: Hayne \& Gibbon, 1928.

15. Durban Borough Water Engineer. Correspondence from Borough Water Engineer to Works Committee re 'Present Position of Water Supply', May 18, 1926. Reports of the Durban Borough Water Engineer, 1925 - 26. Durban: Borough Water Engineer Office, 1926.

16. Christie J. Remarks on 'Kidinga Pepo': A peculiar form of exanthematous disease epidemic in Zanzibar, East Coast of Africa, from July 1870 till January 1871. BMJ 1872;1(596):577-579.

17. Christie J. On epidemics of dengue fever: their diffusion and etiology. Glasgow Med J 1881;3:161-176.

18. Carey D. Chikungunya and dengue: A case of mistaken identity? Hist Med Allied Sci 1971;26(3):243262. https://doi.org/10.1093/jhmas/XXVI.3.243

19. Kuno G. A re-examination of the history of etiologic confusion between dengue and chikungunya. . Kuno G. A re-examination of the history of etiologic confusion between dengue
PLoS Negl Trop Dis 2015:9(11):1-11. https:// doi.org/10.1371/journal.pntd.0004101

20. Halstead S. Reappearance of chikungunya, formerly called dengue, in the Americas. Emerg Infect Dis 2015;21(4):557-561. https://doi.org/10.3201/eid2104.141723

21. Labonte J. Epidemic of dengue in the island of Mauritius in 1873. Edinb Med J 1874;20:322-325.

22. Army Medical Department, Great Britain. On the health of troops serving in the island of Mauritius. Army Medical Department Report for the Year 1873. London: Her Majesty's Stationery Office, 1875:95-100.

23. Durban (From our Correspondent). The Natal Witness 23 January 1874 .

24. Local and General: The Sickness. The Natal Mercury 27 January 1874.

25. Correspondence from District Surgeon, Durban, to Colonial Secretary re: 'Dengue Prevailing in Durban,' March 14, 1878. Folder 966/1878, Box 634, Series CSO (Correspondence of the Colonial Secretary, Natal), KwaZulu-Natal Provincial Archives.

26. The Week. The Natal Mercury 19 March 1878.

27. Rotz PD. The fever next time: Aedes aegypti and the back-to-the-future risk of arbovirus outbreaks in Durban, South Africa. The Pardee Papers (in press).

Durban, South Africa. The Pardee Papers (in press).
28. Rotz PD. Sweetness and Fever? Sugar production, Aedes aegypti, and dengue fever in Natal, South Rotz PD. Sweetness and Fever? Sugar production, Aedes aegypti, and dengue fever in Natal, South
Africa, 1926-27. S. Afr Hist J 2016;68(3):286-303. https://doi.org/10.1080/02582473.2016.1246590

29. Nicholson SE, Entekhabi D. The quasi-periodic behavior of rainfall variability in Africa and its relationship to the southern oscillation. Arch Meteorol Geophys Bioclimatol A 1986;34(3-4):311-348. https://doi.org/10.1007/BF02257765

30. Lindesay JA, Vogel CH. Historical evidence for southern oscillation-southern African rainfall relationships. Int J Climatol 1990;10:679-689. https://doi.org/10.1002/joc.3370100703

31. Nash DJ, Pribyl K, Klein J, et al. Seasonal rainfall variability in Southeast Africa during the nineteenth century reconstructed from documentary sources. Clim Change 2016;134(4):605-619. https://doi. org/10.1007/s10584-015-1550-8

32. Lindeque M. Zika virus: Is SA at risk? Eyewitness News 29 January 2016. http://ewn.co.za/2016/01/29/ WHO-says-Zika-virus-spreads-explosively-4-million-cases-forecast (accessed 9 June 2016).

33. Farber T. 'No risk in SA' as WHO meets on Zika. The Sunday Times 31 January 2016. http://www. pressreader.com/south-africa/sunday-times/20160131/281801397989937 (accessed 9 February 2017).

34. Child K. SA blood not to Zikảs taste. The Sunday Times 1 February 2016. http://www.timeslive.co.za/ 4. Child K. SA blood not to Zika's taste. The Sunday Times 1 February 2016. h
thetimes/2016/02/01/SA-blood-not-to-Zikas-taste (accessed 9 June 2016).

35. Skosana I. Key institutes keep watch on Zika for Africa. Bhekikisa Centre for Health Journalism. 19 February 2016. http://bhekisisa.org/article/2016-02-18-key-institutes-keep-keen-watch-on-zika-forafrica (accessed 9 June 2016).

36. South African Broadcasting Corporation, Digital News. Minister Motsoaledi on Zika virus disease (televised interview). 19 February 2016. https://www.youtube.com/watch?v=5-TdFgkNHmQ (accessed 1 June 2016).

37. Parliamentary Monitoring Group. Minister of Health on Zika virus and typhoid preparedness and response. Briefing given to the Portfolio Committee on Health, Parliament of South Africa (audio recording). 9 March 2016. https://soundcloud.com/pmgza/minister-of-health-on-zika (accessed 28 January 2017).

38. National Institute for Communicable Diseases, South Africa. An update on Zika virus. Commun Dis Commun 2016;15(3):1-2. http://www.nicd.ac.za/assets/files/NICD\%20Communicable\%20 Diseases\%20Communique_Mar2016_final.pdf (accessed 14 April 2016).

39. Van Vuren PJ, Weyer J, Kemp A, et al. Is South Africa at risk for Zika virus disease? S Afr Med I 2016;106(3):232-233. https://doi.org/10.7196/SAMJ.2016.v106i3.10615 
40. Powell JR, Tabachnik WJ. History of domestication and spread of Aedes aegpyti - a review. Mem Inst Oswaldo Cruz 2013;108(Suppl 1):11-17. https://doi.org/10.1590\%2F0074-0276130395

41. Jupp PG, Kemp A, Frangos C. The potential for dengue in South Africa: Morphology and the 1. Jupp PG, Kemp A, Frangos C. The potential for dengue in South Africa: Morph
taxonomic status of Aedes aegypti populations. Mosq Systematics 1991;23(3):182-190.

taxonomic status of Aedes aegypti populations. Mosq Systematics 1991;23(3):182-190.
42. De Meillon B. Proved and potential vectors of yellow fever in South Africa. Bull World Health Organ 1954;11(3):443-451. https://www.ncbi.nlm.nih.gov/pmc/articles/PMC2542194/pdf/
. he Organ 1954;11(3):443-451. https://ww
bullwho00552-0131.pdf (accessed 15 July 2016).

43. Muspratt J. The Stegomyia mosquitoes of South Africa and some neighbouring territories. Mem Entomological Soc South Afr 1956;4:1-138.

44. Kemp A, Jupp PG. Potential for dengue in South Africa: Mosquito ecology with particular reference to Aedes aegypti. J Am Mosq Control Assoc 1991;7(4):574-583.

45. McIntosh BM, Jupp PG. Attempts to transmit chikungunya virus with six species of mosquito. J Med Entomol 1970;7(5):615-618. https://doi.org/10.1093/jmedent/7.5.615

46. Jupp PG, McIntosh BM, dos Santos I, de Moor, P. Laboratory studies on six mosquito and one tick species with chikungunya virus. Trans R Soc Trop Med Hyg 1981;75(1):15-19. https://doi. org/10.1016/0035-9203(81)90005-5

47. Jupp PG, Kemp A. The potential for dengue in South Africa: Vector competence tests with DENV 1 and 2 viruses in 6 mosquito species. Trans R Soc Trop Med Hyg 1993;87(6):639-643. https://doi. org/10.1016/0035-9203(93)90271-q

48. Jupp PG, Kemp A. Laboratory vector competence with yellow fever viruses and five South African mosquito species, including Aedes aegypti. Trans R Soc Trop Med Hyg 2002;96(5):493-498. https://doi. org $110.1016 / 50035-9203(02) 90417-7$

49. Miller BR, Monath TP, Tabachnick WJ, Ezike VI. Epidemic yellow fever caused by an incompetent mosquito vector. Trop Med Parasitol 1989;40(4):396-399.

50. Statistics South Africa. South African Statistics, 2004/05. Pretoria: Stats SA, 2005. https://www.statssa. gov.za/publications/SAStatistics/SAStatistics2004.pdf (accessed 28 July 2016).

51. Christophers SR. Aedes aegypti (L), the Yellow Fever Mosquito: Its Life History, Bionomics, and Structure. Cambridge: Cambridge University Press, 1960.

52. Rueda LM, Patel KJ, Axtell RC, Stinner RE. Temperature dependent development and survival rates of Culex quinquefasciatus and Aedes aegypti (Diptera, Culicidae). J Med Entomol 1990;27(5):892-898. https://doi.org/10.1093/jmedent/27.5.892

53. Tun-Lin W, Burkot TR, Kay BH. Effects of temperature and larval diet on development rates and survival of the dengue vector Ae. aegypti in north Queensland, Australia. Med Vet Entomol 2000;14(1):31-37. https://doi.org/10.1046/j.1365-2915.2000.00207.x

54. De Almeida Costa EAP, de Mendonca Santos EM, Correia JC, de Albuquerque CMR. Impact of small variations in temperature and humidity on the reproductive activity and survival of Aedes aegypti. Rev Bras Entomol 2010;54(3):488-493. https://doi.org/10.1590/s0085-56262010000300021

55. World Health Organization. Global Strategy for Dengue Prevention and Control, 2012 - 2020. Geneva WHO, 2012. http://apps.who.int/iris/bitstream/10665/75303/1/9789241504034_eng.pdf (accessed 9 June 2016).

56. Moreno-Madrinan MJ, Turell M. Factors of concern regarding Zika and other Aedes aegyptitransmitted viruses in the United States. J Medical Entomol 2017;54(2):251-257. https://doi. org/10.1093/jme/tjw212

57. Reiter P, Lathrop S, Bunning M, et al. Texas lifestyle limits transmission of dengue virus. Emerg Infect Dis 2003;9(1):86-89. https://doi.org/10.3201/eid0901.020220

58. eThekwini Municipality. Integrated Development Plan: 2016 - 17 Annual Review. eThekwini: eThekwini Municipality, 2016. http://www.durban.gov.za/City_Government/City_Vision/IDP/ Documents/Final\%202016_17\%20IDP\%2029052016.pdf (accessed 24 July 2016).

59. Statistics South Africa. GHS Series Report, volume VIII: Water and Sanitation, In-depth Analysis of General Household Survey 2002 - 2005 and Community Survey 2016 Data. Pretoria: Stats SA, 2016. http://www.statssa.gov.za/publications/03-18-07/03-18-072015.pdf (accessed 24 July 2016).

60. Durban Corporation. Medical Officer of Health's Report for the year ended 30th June 1927. Durban: Hayne \& Gibson Printers, 1928

61. McClelland GAH. Observations on the mosquito Aedes (Stegomyia) aegypti (L.), in East Africa. II: The biting cycle in a domestic population on the Kenya Coast. Bull Entomol Res 1959;50(4):687-696. https://doi.org/10.1017/S0007485300054729

62. Duffy MR, Chen TH, Hancock WT, et al. Zika virus outbreak on Yap Island, Federated States of Micronesia. N Engl J Med 2009;360(24):2536-2543. https://doi.org/10.1056/nejmoa0805715

63. Bhatt S, Gething PW, Brady OJ, et al. The global distribution and burden of dengue. Nature 2013;496(77446):504-507. https://doi.org/10.1038/nature12060

64. Duong VL, Lambrechts RE, Paul RE, et al. Asymptomatic humans transmit dengue virus to mosquitoes. Proc Natl Acad Sci U S A 2015;112(47):14688-14693. https://doi.org/10.1073/pnas.1508114112
65. Statistics South Africa. General Household Survey: Selected Development Indicators - Metros, 2015. Pretoria: Stats SA, 2015. http://www.statssa.gov.za/publications/Report-03-18-20/ Report-03-18-202015.pdf (accessed 5 July 2016).

66. King Shaka International Airport: Built for the long haul. The SA Mag (undated). http://thesa-mag. King Shaka International Airport: Built for the long haul. The SA Mag (undated). http://thesa-mag
com/features/transport/king-shaka-international-airport-built-long-haul/ (accessed 5 August 2016). com/features/transport//ing-shaka-international-airport-built-long-haul/ (accessed 5 August 2016).
Dube TradePort Corporation. King Shaka International Airport hits new highs 46 percent increase in international passenger growth (press release). 6 September 2016 http://www.dubetradeport.co.za/News/7/Press-Releases-and-Statements/60201 KingShakaInternationalAirporthitsnewhighswitha46percentincreaseininternationalpassengergrowth (accessed 8 October 2016).

68. eThekwini Municipality. Taking Durban to the World: Durban Tourism and Visitor Marketing Strategy, 2013 - 2020. Durban: eThekwini Municipality, 2012. http://www.durbanexperience. co.za/Media/Download/Documents/Strategies/Durban\%20Visitor\%20Marketing\%20Strategy\%20 Summary\%20booklet.pdf (accessed 24 July 2016)

69. eThekweni Municipality, Environment Planning and Climate Protection Department. Durban Climate Change Strategy. Durban: eThekweni Municipality, 2014. http://www.durban.gov.za/City_Services/ energyoffice/Documents/DCCS_Final.pdf (accessed 6 June 2016).

70. Watts DM, Burke DS, Harrison BA, Whitmire RE, Nisalak A. The effect of temperature on the vector efficiency of Aedes aegypti for dengue 2 virus. Am J Trop Med Hyg 1987;36(1):143-152. https://doi. org/10.4269/ajtmh.1987.36.143

71. Rohani A, Wong YC, Zamre I, Lee HL, Zurainee MN. The effect of extrinsic incubation temperature on development of dengue serotype 2 and 4 viruses in Aedes aegypti (L). Southeast Asian J Trop Med Public Health 2009;40(5):942-950. http://www.tm.mahidol.ac.th/seameo/2009-40-5/12-4570.pd (accessed 10 August 2018).

72. Reiter P. Climate change and mosquito-borne disease. Environ Health Perspect 2001:109(1):141-161 https://doi.org/10.2307/3434853

73. Beebe NW, Cooper RD, Mottram P, Sweeney AW. Australia’s dengue risk driven by human adaptation to climate change. PLoS Negl Trop Dis 2009;3(5):e429. https://doi.org/10.1371/journal.pntd.0000429

74. Sutherland PCG, Meller HJ, Addison WH. Report on the Government Hospital, Durban. 20 June 1871 Box 103, Series CO 179, Public Records Office, The National Archives of the UK.

75. Durban (from our Correspondent). The Natal Witness 16 February 1877.

76. Durban Township Water Supply Commission Evidence, June - July 1898. Box 2836, Series CSO (Correspondence of the Colonial Secretary, Natal), KwaZulu-Natal Provincial Archives.

77. Correspondence from Harbour Department Engineer to Secretary of Railways and Harbours, re 'Notices received from Health Department ordering the removal from their premises of all water 'Notices received from Health Department ordering the removal from their premises of all water
tanks', 12 January 1906. Folder 72/1906, Box II/1/95, Series NHD (Records of the Natal Harbour tanks', 12 January 1906 . Folder $72 / 1906$, Box $11 / 1 / 95$
Department), KwaZulu-Natal Provincial Archives.

Department), KwaZulu-Natal Provincial Archives.
78. Office of the Chief Sanitary Inspector, Report on Activities in Connection with Anti-Mosquito Campaign, 5 April 1928. Folder 184, volume 3 (Eradication of Flies and Mosquitoes), Box 4/1/2/831 Series 3/DBN (Records of the Durban Town Clerk), Durban Archives Repository.

79. Borough of Durban, Annual Report of Borough Medical Officer of Health, Year Ending 30th June 1935. Durban: Durban Corporation, 1935.

80. Golder \& Associates. Community-based Adaptation to Climate Change in Durban. Durban: eThekweni Municipality, 2011.

81. eThekwini Water and Sanitation. Good Science Makes Good Policy: eThekwini Water and Sanitation Innovations, 2012. Durban: eThekwini Municipality, 2012. http://prg.ukzn.ac.za/docs/default-source/ supporting-documentation/ews-innovations-2012.pdf?sfvrsn=2 (accessed 10 December 2017).

82. eThekwini Municipality. Nexus: Projects Under taken by the eThekwini Municipality, Durban. Durban, eThekweni Municipality, 2013. http://prg.ukzn.ac.za/docs/default-source/ews/nexusDurban, eThekweni Municipality, 2013. $\mathrm{htt}$,
booklet-final.pdf?sfrrsn=2 (accessed 24 July 2016).

83. Galvin M. A hot climate for civil society engagement with climate change and water in Durban. In: Perkins PE, ed. Water and Climate Change in Africa: Challenges and Community Initiatives in Durban, Maputo and Nairobi. New York: Routledge, 2013:63-70.

84. eThekwini's 10-year water security plan. Daily News 1 August 2017. https://www.iol.co.za/dailynews ethekwinis-10-year-water-security-plan-10577656 (accessed 20 September 2017)

85. Trewin B, Darbo J, Jansen C, et al. The elimination of the dengue vector, Aedes aegypti, from Brisbane, Australia: The role of surveillance, larval habitat removal and policy. PLoS Negl Trop Dis 2017;11(8):e0005848. https://doi.org/10.1371/journal.pntd.0005848

S Afr Med J 2018;108(5):364-366. DOI:10.7196/SAMJ.2018.v108i5.12900 